\title{
VALUE ADDED EXPORTS AND COMPETITIVENESS IN THE BALTIC STATES
}

\author{
Velga Ozolinga \\ Faculty of Engineering Economics and Management, Riga Technical Univertisy, \\ Kalnciema str. 6, LV-1048 Riga, Latvia \\ E-mail:velga.ozolina@rtu.lv
}

\begin{abstract}
The paper is devoted to the analysis of the exports and competitiveness in the Baltic States from the trade in value added perspective. The main objective is to determine the differences in export patterns measured in gross terms and in value added terms and the implications on competitiveness. Focusing on the recent trend to facilitate high value added exports, the article describes high- and medium-high-tech industries as classified by the EUROSTAT in more detail. OECD database is used for the study purposes, data are analysed using different statistical methods, including the calculation of relative indicators and regression analysis. The results show that Lithuania seems to be more competitive Baltic Country in general terms, but Latvia is lagging behind in the sector of high- and medium-high-tech industries.
\end{abstract}

Keywords: Baltic States, exports, trade in value added, competitiveness, high- and medium-high industries.

JEL Classification: F100; F140; F190.

\section{Introduction}

Competitiveness is a widely discussed issue and it is topical in several levels. Competitiveness issues are analysed in national or country level, in the level of industries or sectors, in the level of enterprises, as well as goods and services. One of the important focal points is the export competitiveness, because exports is one of the elements of economic growth. It is especially vital in the countries with small domestic markets or slow development of the domestic economy. Export competitiveness is in many cases analysed together with the export promotion activities (see Cadot et al. 2015; Lowry 2014). The reason for that is the possibility to increase the export volumes and/or values by facilitating exporter activities, which would then lead to the further development of the economy. Relations between the export characteristics and economic growth are also analysed (Mejía 2011; Vukšić 2015; González-Pernía, PeñaLegazkue 2015). Thus it is crucial to determine, which factors influence export competitiveness and consequently which instruments are better suited for export promotion.

Different export competitiveness influencing factors are analysed in a wide range of studies. Many of these are based on the general perception that the competitive advantage can be related to the price and the quality of the product. Moreover, different countries may be associated with the different price and quality levels, also the situation in particular sectors or regarding particular products may differ. Several authors suggest that in many cases price competitiveness in not the main factor or at least no the only factor influencing competitiveness. Even more attention is paid to the technologies and different qualitative factors like capital stock, productivity, R\&D activities, innovativeness and political stability (Athanasoglou, Bardaka 2010; Benkovskis, Wörz 2015; Bojnec, Fertő 2015; Bournakis 2013; Christodoulopoulou, Tkačevs 2015; Dosi et al. 2015; Kostoska, Mitrevski 2015; Mirdala 2015; Sabonienė 2014; Verheyen 2014).

Another important aspect related to the competitiveness studies is the vertical trade. International integration of the production processes has led to the situation, when the standard trade statistics do not always show the realistic picture of the competition. For example, it is said that the industrial and geographic patterns can be very different, when the value-added trade is compared with the standard trade (Daudin et al. 2011; Koopman et al. 2014). It means that if the product of one country is exported to another country, it does not necessary imply that this product has to attract demand in that country, because it can be used in production and then exported to another country for final use. Moreover, bilateral trade imbalances measured in the value added terms are different from gross trade imbalances (Johnson, Noguera 2012). 
Analysis of the trade in the value added can be used to understand, whether it is useful to facilitate the exports of the high-value added products in a particular country, or such products are associated more with the foreign value added. Another option would be to improve the production process in such a way as to reduse the re-imported share of exports. In other words, it is possible to conclude, whether the exports in a particular industry facilitates domestic or foreign growth. For example, it is estimated that every US\$1000 of China's exports generates US\$ 506.8 of national income (Duan et al. 2012). Similarly analysis of the domestic content of the production and demand components may lead to different values and trends in the competitiveness indicators.

The main objective of this study is to determine the differences in the export patterns measured in gross terms and in value added terms and the implications on the competitiveness in the Baltic States.

\section{Data and methodology}

The research is based on the OECD Trade in Value Added (TiVA) database (OECD 2015). This database contains information on several indicators (including value added, output, final demad, exports and imports) by industries in NACE $1.1 \mathrm{ed}$. classification for years 1995, 2000, 2005 and 2008-2011. Thus the results of the analysis cannot be directly related to the newer data available in NACE 2 ed. Therefore it is important to analyse the relations among indicators available in TiVA with the indicators available also elsewhere.

More attention is paid to the high- and medium- tech industries. According to the Eurostat (2016) classification, high-tech industries are the industries with the NACE 1.1 codes 30,32 and 33, to the medium-high-tech industries belong the industries with the codes 24, 29, 31, 34 and 35 and to the medium-low-tech industries belong the industries with the codes 23, 25-28.

Several indicators were used in the analysis from the TiVA database. These are gross exports, domestic value added in exports, domestic value added in foreign final demand, value added and output. These indicator are then used to calculate different shares (regional shares, share of the value added exported further and specialization indicators), ratios (domestic value added in exports to gross exports, domestic value added in the foreign final demand to domestic value added in exports, value added to output) and revealed comparative advantage (RCA) index. The share of the value added exported further is calculated as the ratio of the difference between the domestic value added in exports and domestic value added in foreign final demand to the domestic value added in exports. The values of this indicator shows both the share of goods exported back to the source countries and to the other countries.

RCA indexes are widely used in different studies of export competitiveness. RCA index is calculated using equation (1), adapting the formula used in (Bojnec, Fertő 2015) and several other studies. In this study 3 indicators are used for calculations as the export indicator - gross exports (RCA1), domestic value added in exports (RCA2) and domestic value added in foreign final demand (RCA3). It is argued that exports in value added terms lead to more informative values of RCA index (Brakman, Van Marrewijk 2016; Ceglowski 2015).

$$
R C A=\left(\frac{X_{i, j}}{X_{j}}\right) /\left(\frac{X_{i}}{X}\right),
$$

where: $X_{i, j}$ - exports of the industry $i$ in the country $j ; X_{j}$ - total exports in the country $j ; X_{i}-$ global exports of the industry $i ; X-$ global exports.

In order to analyse, wheather it is possible to use more recent data to get some hints on the development of the domestic value added exported and demanded abroad, regression analysis is used as well.

\section{The Baltic States in the World economy}

Estonia, Latvia and Lithuania are small open economies, which are strongly influenced by the economic fluctuations in other countries. It can be clearly seen also in the data on the shares of the value added of each country in the global economy (see Fig. 1). After the rapid growth of the size of the economy in each Baltic country till 2008, the decrease due to the global financial crisis followed not only in absolute terms, but also relative to the World economy.

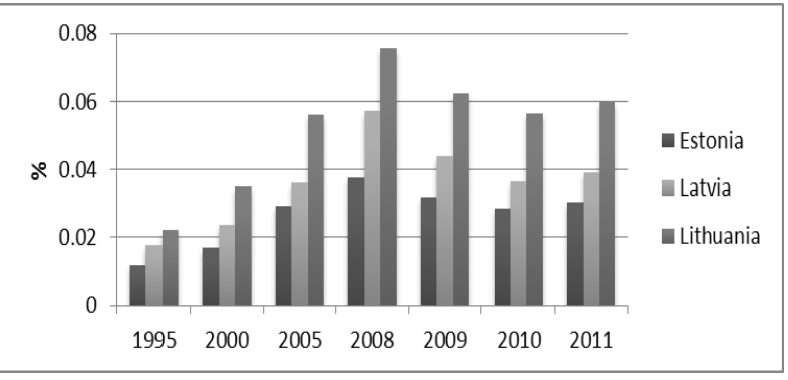

Fig. 1. The share of the value added of the Baltic States in the World Economy, \% (Source: calculated by the author, using data of OECD 2015) 
On the other hand, export dynamics are more positive for all three countries, leading to the decrease in exports and even the value added exports and the foreign demand of the domestic value added only in 2009 and to the slight changes in terms of shares in the World economy (see Fig. 2).

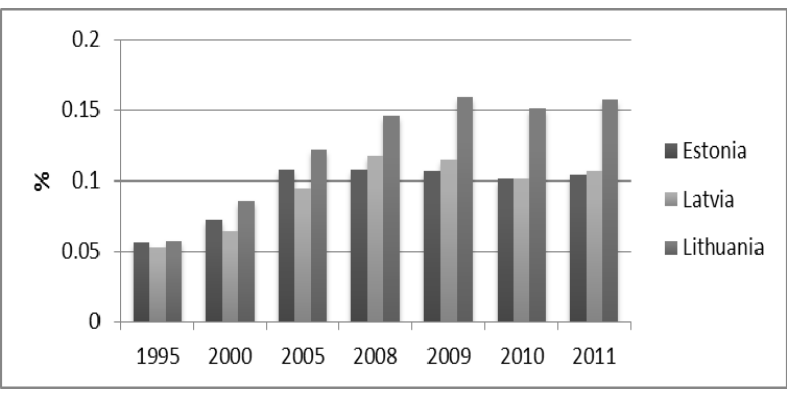

Fig. 2. The domestic value added of the Baltic States in the foreign final demand as the share of the World Economy, \% (Source: calculated by the author, using data of OECD 2015)

It means that the exporters of the Baltic States generally were increasing their competitiveness till 2008 (Lithuania till 2009) and afterwards have remained their competitiveness, relative to the average exporter in the World. Moreover, exporters seem to be able to adapt to the global changes more quickly, as the development and demand in other countries is not homogenuous. Higher demand growth in some countries may at least partly offset the negative trends or weak demand in the other countries.

All the Baltic Countries export their goods and services mainly to the European countries (78$81 \%$ in 2011). However, it is interesting to note that Estonia concentrates more on the EU15 countries (export thare is larger than $50 \%$ in all analysed years), but Latvia and Lithuania export twice as significant share as Estonia to the 13 new member states of the EU (more than $20 \%$ in 2008 2011), although the share of exports to the EU15 countries is still high (37-41\%). Also the shares of the other regions as export partners indicate that the Latvian and Lithuanian exports are more diversified.

Another important aspect of exports as a facilitator of economic growth of a country, is the share of the domestic value added actually being exported. Figure 3 demonstrates that Lithuania is advancing in this aspect followed by Latvia with more than $70 \%$ of domestic value added content of exports. The share of exported Estonian value added is mostly less than $70 \%$ and is more volatile.

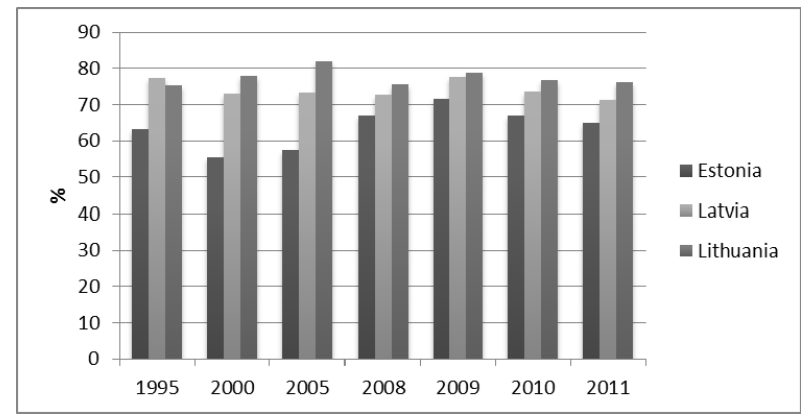

Fig. 3. The share of the domestic value added in exports of the Baltic States, \% (Source: calculated by the author, using data of OECD 2015)

It is also clear that not all the goods and services, which are exported to a particular country, are meeting the final demand there. Ratios of the domestic value added contents of the foreign final demand to the gross exports show that there are regions, which get the products of the Baltic States indirectly. There are also regions, which use the products of the Baltic States to export these further (processed or not). South and Central America belongs to the first group for all three Baltic States and East and South East Asia as well as North American Free Trade Association - for Latvia and Lithuania, while the other regions belong to the latter group. It means that the Baltic States use the proximity of the export markets (including such benefits as the common market, common language, common border etc.) as one of the main drivers of exports. This idea is frequently used also in gravity models, which state that the trade volumes between two countries are determined by the size of each country, by the transportation costs (distance and other related factors) and other factors like common language, common currency, infrastructure, international agreements etc. (see Gallego, Llano 2014; Lawless 2010; Håkanson 2014; GomezHerrera et al. 2014; Lameli et al. 2015 and others for more information).

Close relationhsips between the Baltic States and the other European countries can be seen also in the structure of the value added of exports by sources. In 2011 besides the high share of domestic value added $(65 \%$ in Estonia, $71 \%$ in Latvia and $76 \%$ in Lithuania), significant share of the value added from other European countries was used for exports as well $(27 \%, 23 \%$ and $20 \%$ respectively, mostly from the EU28 countries). The shares of the other regions were not higher than $5 \%$ in any of the analysed periods.

Regarding the recent tenstion between the EU and Russia, it is also worth analysing the role of Russia in the gross exports of the Baltic States. The 
share of Russia as the export partner has decreased in all the Baltic States. In Estonia it fell from 13\% in 1995 to $9 \%$ in 2011, in Latvia it fell from $18 \%$ to $11 \%$ and in Lithuania from $28 \%$ to $11 \%$. Similar trends are present in the exported domestic value added and domestic value added in the final demand of Russia. The importance of Russia is decreasing also as a source of exports in the Baltic States. Although the share of Russian value added in the export sources structure is less than $4 \%$ in Estonia and Latvia and 7\% in Lithuania in 2011, it comprises more than $11 \%$ of the foreign value added of exports in Estonia and Latvia and almost $30 \%$ in Lithuania in the respective period.

\section{Intra-Baltic trade analysis}

According to the gravity approach mentioned before, neighbouring countries tend to trade more than distant ones. However, the question arrises, wheather they also cooperate more. Figure 4 shows that indeed the trading relationships are tighter between Latvia and Lithuania and between Latvia and Estonia. Moreover, export and import values are very similar for each pair of the countries. In terms of export structure, Latvia exports to Lithuania $12 \%$ of its exported goods and services and gets $10 \%$ of the Lithuaninan exports (in 2011). Latvia exports $8 \%$ of exported goods and services to Estonia and get 7\% of the Estonian exports in the same period. Estonia exports to Lithuania 6\% of its exports and gets $2 \%$ of Lithuanian exports. Trends are very similar, if the value added exports and the domestic value added in foreign final demand is analysed.

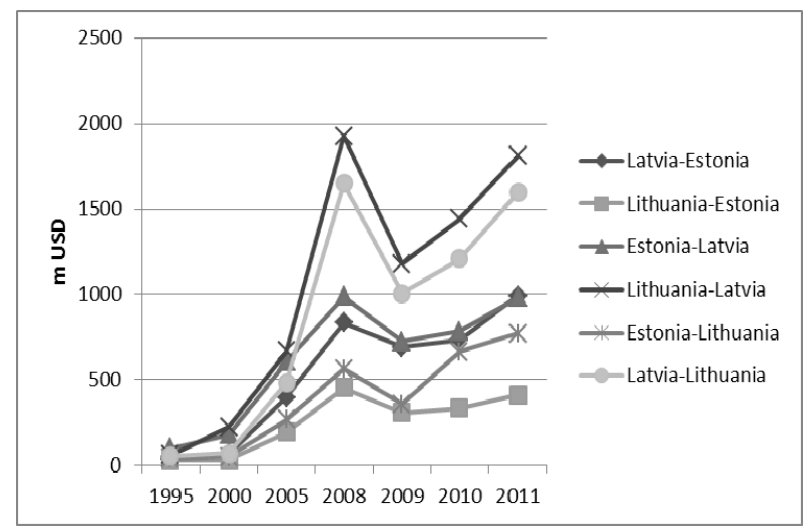

Fig. 4. Gross exports between the Baltic States, m USD (Source: calculated by the author, using data of OECD 2015)

The dynamics of the shares of exported value added not demanded in the export partner country are showen in Figure 5. Here we see that Estonia is the country, which uses the highest share of the other countries' value added to export it further and the share of the value added of Latvia is considerably higher than the share of Lithuania. The second in this respect is Latvia and in this case the shares of the Estonian and Lithuanian value added for further exprots are very similar. Lithuania does not use as much of the Latvian and Estonian value added for further exports as the other Baltic States. However, in 2010 and 2011, these shares have increased.

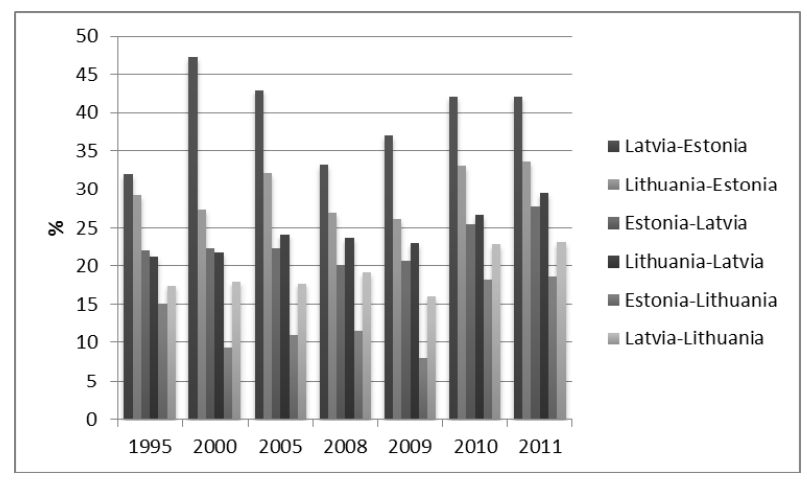

Fig. 5. Share of the value added exported further, \% (Source: calculated by the author, using data of OECD 2015)

It can be concluded that the Baltic Countries play a significant role in exporting the value added of each other, therefore there is a room for discussion regarding the further collaboration of the Baltic States in the exporting process.

\section{Analysis of the high- and medium-high-tech industries}

In the group of high-tech industries globally dominate East and South East Asian countries both in terms of the value added and exports. Thus it is not likely for European countries to achieve the high growth rates in this sector, although exceptions may always exist.

Within the Baltic States Estonia seems to be that exception (see Fig. 6). Its shares in the global high-tech industry exports are fluctuating, however they tend to be much higher than in the other Baltic States. On the other hand, the share of the domestic value added in exports is comparatively lower in Estonia with wide fluctuations. The shares of the domestic value added in the Latvian and Lithuanian exports are fluctuating around $60 \%$. It is interesting to note that intra-Baltic export analysis reveals that the highest rates of the further exports of the Latvian and Lithuanian exports are in the same years as the highest Estonian shares in the global 
market. It means that Estonia is able to use the Latvian and Lithuanian products to increase its global market share. Also Lithuania tends to export further more than $50 \%$ of the Latvian exports in 2010 and 2011.

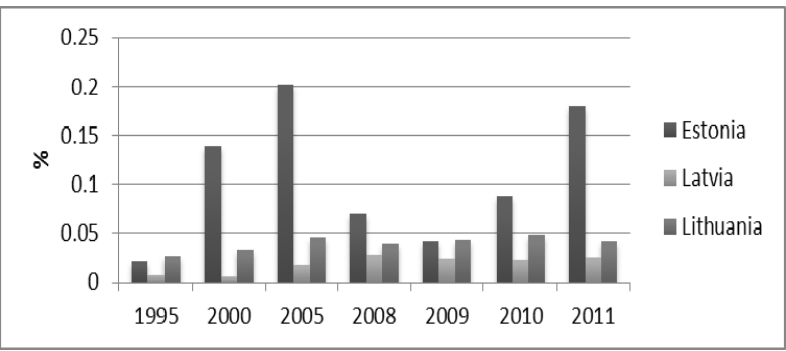

Fig. 6. Global export shares of the high-tech industries of the Baltic States, \% (Source: calculated by the author, using data of OECD 2015)

Also the export structure indicates that Estonia aims to specialize in the high-tech exports. The values of the RCA1 index (based on gross exports) is higher than in the other Baltic States and exceeds 1, which indicates on the presence of the competitive advantage. In Latvia and in Lithuania the values of RCA are fluctuating below 0.5 with the general growing trend in Latvia and decreasing trend in Lithuania. In case of Estonia, it should be noted, that the values of RCA indexes are significantly different in 2000 and 2005, depending on the data used for calculations. Classical RCA using gross exports (RCA1) shows, that Estonia had a comparative advantage while the value added exports (RCA2) and the domestic value added in foreign final demand (RCA3) does not indicate on such an advantage (see Fig. 7). However, in other periods both the values and the dynamics are very similar, which is also true for Latvia and Lithuania. It means that RCA values have to be interpreted with caution.

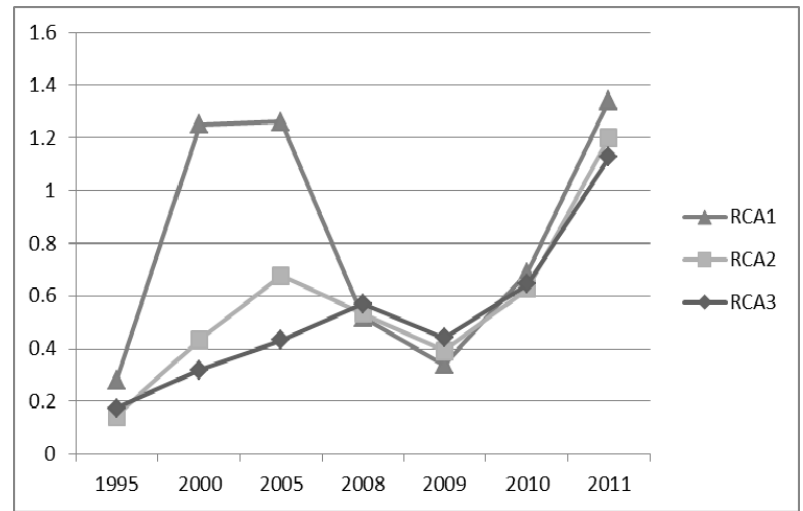

Fig. 7. Revealed comparative advantage index dynamics for high-tech industries in Estonia, \% (Source: calculated by the author, using data of OECD 2015)
One of the ways to check for possible overestimation of the comparative advantage in a particular period of time, is to analyse the relationship between the shares of the domestic value added in exports and value added to output. Figure 8 shows that the relationship between the mentioned indicators is very stong (correlation coefficient value for Estonia is 0.98 , for Latvia 0.85 and for Lithuania $0.78)$.

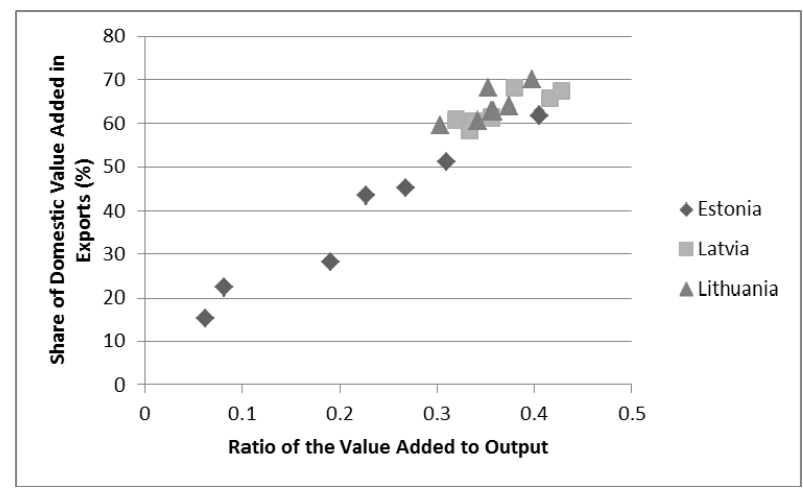

Fig. 8. Relations between the share of domestic value added in exports and the ratio of the value added to ouptut in the high-tech industries in the Baltic States, $\%$ (Source: calculated by the author, using data of OECD 2015)

However, if the data on the domestic value added in exports are not available, data on the value added and classical RCA have to be tested. In case outliers are found, an equation should be estimated without these outliers and afterwards RCA should be modified. Figure 9 shows the modified RCA index (RCA1) of the Estonian high-tech industries compared with its initial value (RCA1) and RCA based on the domestic value added in exports (RCA2).

Trends of the modified RCA1 and RCA2 are not identical, however now the values of the index seem more reliable. The proposed methodology

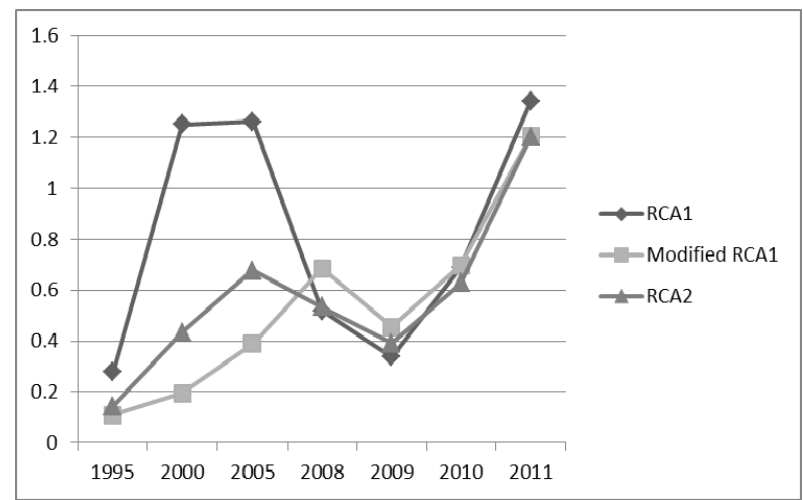

Fig. 9. modified revealed comparative advantage index for Estonia, \% (Source: calculated by the author, using data of OECD 2015) 
has to be tested yet. Nevertheless, it provides an insight to possible consistency checks of the RCA results.

The idea that the RCA calculated with the gross export indicators may be sometimes misleading, is substantiated by the analysis of the ratios of the domestic value added in foreign final demand to the domestic value added exports (see Fig. 10). In other words, this ratio shows the share of the value added exports, which is returning to the domestic market. In 2000 and 2005 more than $50 \%$ of the high-tech industries exports were re-imported to Estonia. It means that Estonia boosted its exports by re-importing its own products and not by increasing its competitiveness as such.

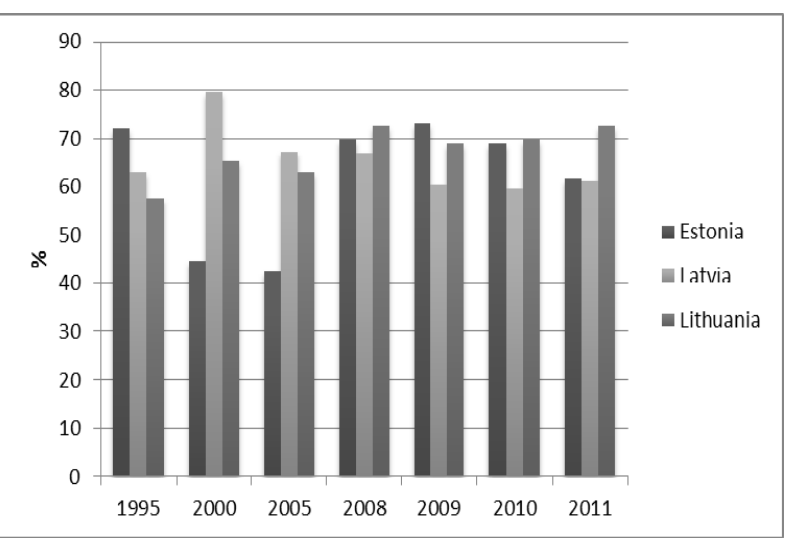

Fig. 10. Ratio of the domestic value added in foreign final demand to the domestic value added exports in the high-tech industries in the Baltic States, \% (Source: calculated by the author, using data of OECD 2015)

Thus the outliers in the relationship between the value added and the standard RCA index may indicate that the share of the re-imported value added is relatively high or low as compared to the general trend.

One of the possible explanations for the move back to the low shares of the re-imports in Estonian case might be consistent move towards the changes in the value chain of the high-technology products so that larger share of the value added is generated in Estonia and not elsewhere.

Analysis of the origin of the exported value added in the high-tech industries shows the dominant role of the European countries. In Latvia and Lithuania the European shares in the exported foreign value added are between $72 \%$ and $83 \%$, while in Estonia they are less than $70 \%$. Moreover, in 2000 in Estonia other regions formed larger part of the foreign export sources than Europe. Also the share of the East and South East Asia, which is the second most important region, is considerably larger in Estonia. The share of Russia is less than
4\% in Estonia, less than 7\% in Latvia and less than 14\% in Lithuania in 2011.

In the medium-high-tech industries globally Europe has the highest share in gross exports, but it is gradually declining and in 2011 is $38 \%$ down from $43 \%$ in 1995. East and South East Asia has increased its share from $25 \%$ in 1995 to $33 \%$ in 2011 and North American Free Trade Association decreased the share from $24 \%$ to $16 \%$ in the same period.

The shares of the Baltic States are fluctuating without clear trends and Latvia is in a comparatively less advantegous situation (see Fig. 11). On the other hand, the share of the domestic value added in exports is higher in Latvia in 2009-2011 and similarly as in Lithuania it is more than $60 \%$, while in Estonia this share fluctuates around 50\%. Analysis of the intra-Baltic trade shows that arount $40 \%$ of the medium-high-tech industries exports are exported further, moreover, between Estonia and Latvia the share is even $50 \%$.

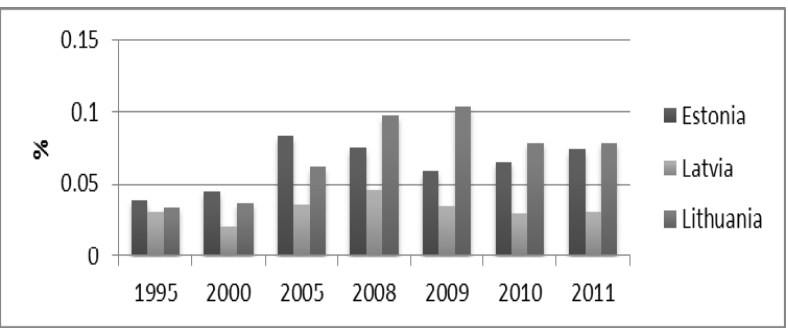

Fig. 11. Global export shares of the medium-high-tech industries of the Baltic States, \% (Source: calculated by the author, using data of OECD 2015)

Values of the RCA indexes independent of the indicators used for their calculations, are below 1 for all the Baltic States and do not have clear trends - a comparative advantage is not revealed here. It can be added that the values of the RCA indexes calculated using all three options are comparatively similar, they differ a bit more in Estonia and the most in Lithuania. However the trends are similar, thus it is possible to judge, if the competitiveness is increasing or decreasing.

Similarly as in the case of the high-tech industries, also in the medium-high-tech industries the correlation between the ratio of the value added to output and the share of the domestic value added in exports is strong (see Fig. 12). The values of the correlation coefficient are high for Latvia and Estonia $(r=0.77)$ but low for Lithuania for the whole period $(\mathrm{r}=0.39)$, however high in 2000-2011 $(\mathrm{r}=0.75)$. Even stonger relationship exists between the ratio of the value added to output and the ratio of the domestic value added in foreign final demand to gross exports. 


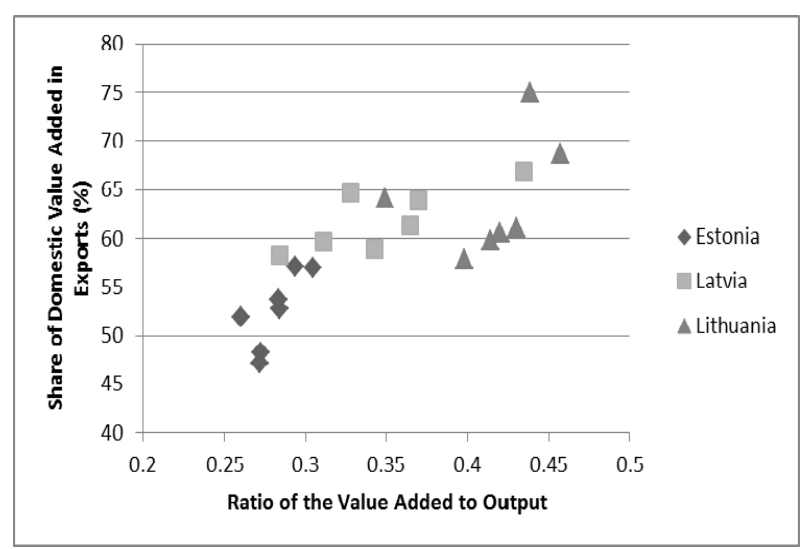

Fig. 12. Relations between the share of domestic value added in exports and the ratio of the value added to ouptut in the medium-high-tech industries in the Baltic

States, \% (Source: calculated by the author, using data of OECD 2015)

The ratios of the domestic value added in foreign final demand to the domestic value added in exports are more stable than in the high-tech industries (see Fig. 13). The ratio for Estonia has gradually decreased to $60 \%$ in 2011 , in Latvia it has increased to $75 \%$ (mainly after the crisis) and in Lithuania even $90 \%$ of exported domestic value added is meeting the final demand abroad. With the respect of Latvia it may indicate on some important structural changes in the medium-high-tech industries as a reaction to the deep crisis. On the other hand, it may indicate that the countries, which were using Latvian products for reexport activities were seeking for lower price options elsewhere.

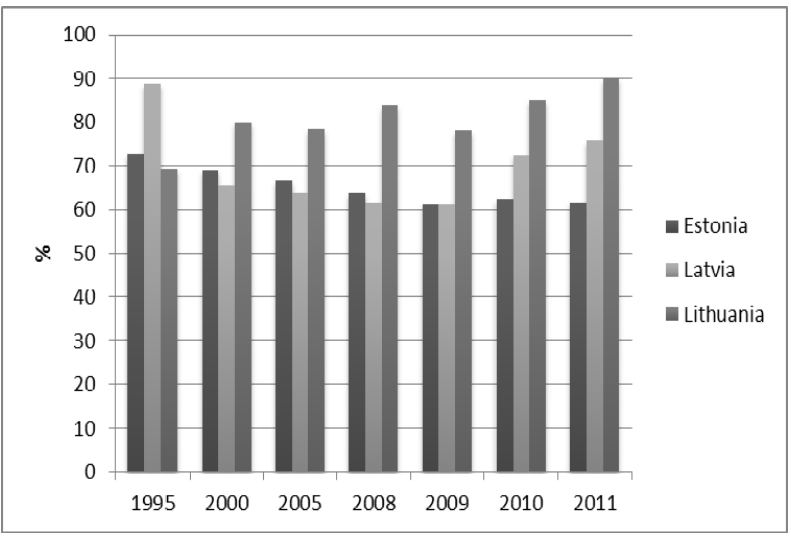

Fig. 13. Ratio of the domestic value added in foreign final demand to the domestic value added exports in the medium-high-tech industries in the Baltic States, \% (Source: calculated by the author, using data of OECD 2015)

In the structure of the foreign export sources Europe dominates with $70-90 \%$ in all the Baltic States. The role of Russia is higher if compared with the high-tech industries - in 2011 Russian share in the foreign value added in exports was $9 \%$ in Estonia, $11 \%$ in Latvia and $48 \%$ in Lithuania. These high shares are related mostly to raw materials and energy sources.

In the medium-low-tech industries there is not a global leader regionally - similar positions take Europe, East and South East Asia and other regions. However, in the group of the Baltic States Lithuania is a clear leader (see Fig. 14). Lithuania also exports the highest share of the domestic value added, which is close to $80 \%$. Domestic value added share of the Estonian and Latvian exports is between $50 \%$ and $60 \%$. Analysis of the intra-Baltic trade reveals that more than $50 \%$ of the Latvian and Lithuanian exports to the other Baltic Countries is exported further. The share of the further exports for Estonia fluctuates between $35 \%$ and $55 \%$.

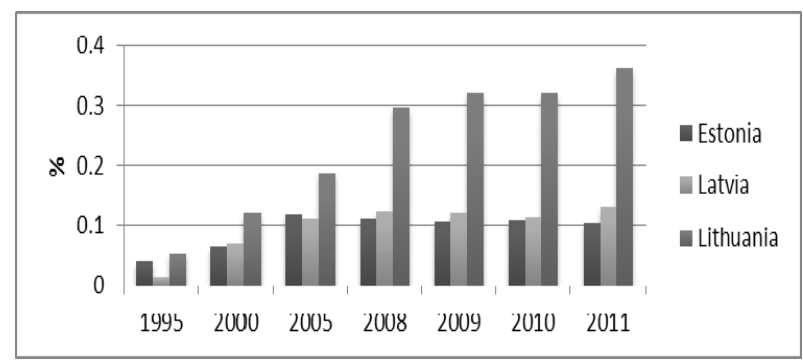

Fig. 14. Global export shares of the medium-low-tech industries of the Baltic States, \% (Source: calculated by the author, using data of OECD 2015)

Analysis of the export specialization leads to a conclusion that Lithuania is focusing on the low-tech industries exports, if the gross exports and the domestic value added exports is used. However in terms of the domestic value added in foreign final demand, all the Baltic Countries have similar positions in terms of the low-tech industries shares in their exports.

The values of the RCA indexes calculated using different indicators for the medium-low-tech industries are further apart. Morover, the values of RCA1 and RCA3 are closer for Estonia (see Fig. 15a), but the values of RCA2 and RCA3 are comparatively closer for Lituania (see Fig. 15b) and Latvia. For Estonia it would imply that the standard RCA would show realisticly both the trends of the competitiveness in terms of the gross exports and the foreign final demand. Thus it does not matter, whether Estonia exports goods directly or via the other industries. In Latvia and Lithuania it implies that export success is partly related to the re-imports. 


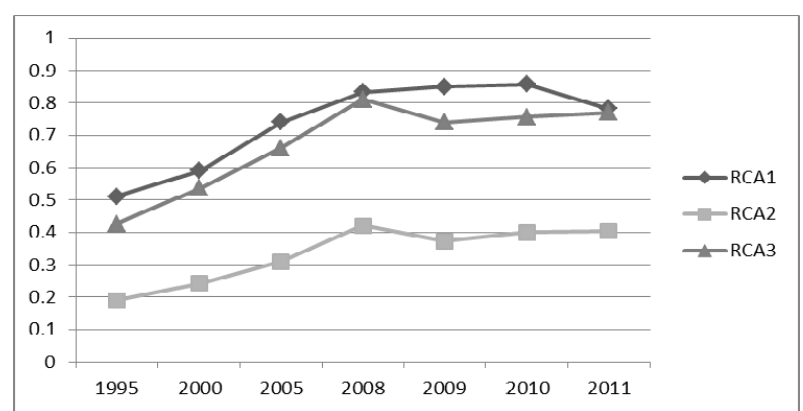

a. Estonia

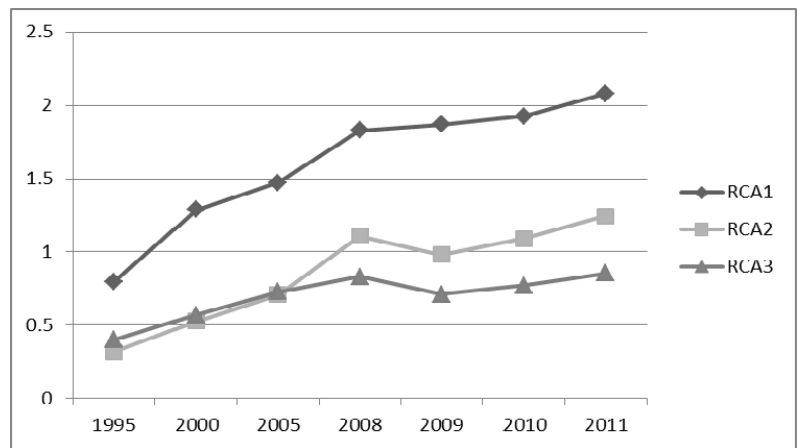

b. Lithuania

Fig. 15. Revealed comparative advantage index dynamics for medium-low-tech industries, \% (Source: calculated by the author, using data of OECD 2015)

Unlike in the High- and Medium-High-Tech industries, relationship between the ratio of the value added to output and the share of the domestic value added exports is not strong in all the Baltic States. However there is a strong correlation between the ratio of the value added to output and the ratio of the domestic value added in foreign final demand to gross exports (see Fig. 16). It means that the trends in the value added per unit of output may reveal similar trends in the domestic value added demanded abroad.

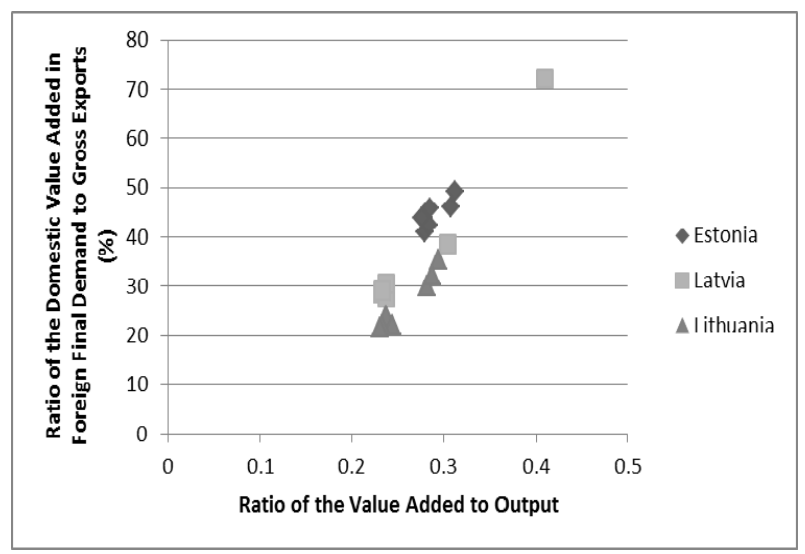

Fig. 16. Relations between the ratio of domestic value added in foreign final demand to exports and the ratio of the value added to ouptut in the medium-low-tech industries in the Baltic States, \% (Source: calculated by the author, using data of OECD 2015)

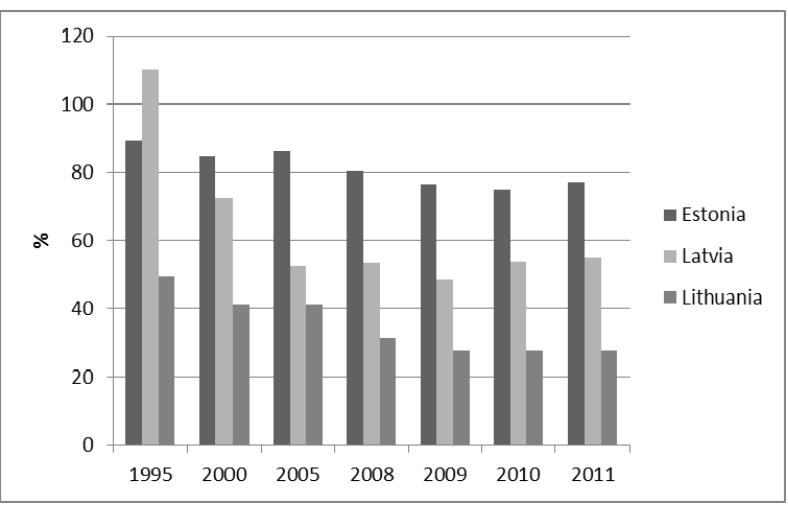

Fig. 17. Ratio of the domestic value added in foreign final demand to the domestic value added exports in the medium-high-tech industries in the Baltic States, \% (Source: calculated by the author, using data of OECD 2015)

Figure 17 shows that $80 \%$ of the Estonian exported value added, more than $50 \%$ of the Latvian exported value added and only about $30 \%$ of the Lithuanian value added is demanded abroad in 2011. Thus Estonia sustains its global market share and the comparative advantage both directly and indicrectly, that is, trough further exports of other countries.

This substantiates the findings of the RCA analysis as the high share of re-imports suggests that the comparative advantage may be overstated if gross exports is used as the basis for calculations.

\section{Conclusions}

Analysis shows that Lithuania is a more competitive Baltic Country in general terms as it has been able to take the largest share in the global market. However, in the group of the high-tech industries Estonia is the leader. On the other hand, it seems that Estonia re-imports a larger share of its own value added.

The values of the RCA index differs, if the value added indicators are used instead of the gross exports. These differences can partly be explained by the re-imports. The higher the share of reimports, the higher the differences in RCA values based on different export indicators. The values of the RCA tend to differ more in the lower-tech industries. In this case, if the values of the RCA index calculated using the gross exports are similar to those calculated using the domestic value added in foreign final demand, then a particular industry is using channels through other industries in order to export its production, however it does not reduce its competitiveness. 
The ratio of the value added to output can be used to analyse the trends in the share of the domestic value added in exports or the ratio of the domestic value added in foreign final demand to gross exports. If the value of the ratio of the value added to output increases, the higher share of the value added is exported or demanded abroad.

As all the Baltic States are using the value added of neighbours to export it further, further developments in the cooperation between the Baltic States can be discussed regarding the joint efforts towards the facilitation of exports also in the high- and medium-high-tech industries.

\section{Funding}

The paper was supported by the National Research Program of the Republic of Latvia 5.2. "Economic Transformation, Smart Growth, Governance and Legal Framework for the State and Society for Sustainable Development - a New Approach to the Creation of a Sustainable Learning Community (EKOSOC-LV)".

\section{References}

Athanasoglou, P. P.; Bardaka, I. C. 2010. New trade theory, non-price competitiveness and export performance, Economic Modelling 27(1): 217-228. http://dx.doi.org/10.1016/j.econmod.2009.09.002

Benkovskis, K.; Wörz, J. 2015. Non-price competitiveness of exports from emerging countries, Empirical Economics, 1-29.

http://dx.doi.org/10.1007/s00181-015-1015-y

Bojnec, Š.; Fertő, I. 2015. Agri-Food Export Competitiveness in European Union Countries, JCMS: Journal of Common Market Studies 53(3): 476492. http://dx.doi.org/10.1111/jcms.12215

Bournakis, I. 2013. Costs, knowledge and market structure: understanding the puzzle of international competitiveness with Greek export data, International Review of Applied Economics 28(2): 240 269.

http://dx.doi.org/10.1080/02692171.2013.858669

Brakman, S.; Van Marrewijk, C. 2016. A closer look at revealed comparative advantage: gross-versus value-added trade flows, Papers in Regional Science, 1-32. http://dx.doi.org/10.1111/pirs. 12208

Cadot, O.; Fernandes, A. M.; Gourdon, J.; Mattoo, A. 2015. Are the benefits of export support durable? Evidence from Tunisia, Journal of International Economics 97(2): 310-324.

http://dx.doi.org/10.1016/j.jinteco.2015.07.005

Ceglowski, J. 2015. Assessing Export Competitiveness through the Lens of Value Added, The World Economy, 1-22. http://dx.doi.org/10.1111/twec.12362
Christodoulopoulou, S.; Tkačevs, O. 2015. Measuring the effectiveness of cost and price competitiveness in external rebalancing of euro area countries: What do alternative HCIs tell us?, Empirica, 1-45. http://dx.doi.org/10.1007/s10663-015-9303-5

Daudin, G.; Rifflart, C.; Schweisguth, D. 2011. Who produces for whom in the world economy?, Canadian Journal of Economics/Revue canadienne d'économique 44(4): 1403-1437.

http://dx.doi.org/10.1111/j.1540-5982.2011.01679.x

Dosi, G.; Grazzi, M.; Moschella, D. 2015. Technology and costs in international competitiveness: from countries and sectors to firms, Research Policy 44(10): 1795-1814. http://dx.doi.org/10.1016/j.respol.2015.05.012

Duan, Y.; Yang, C.; Zhu, K.; Chen, X. 2012. Does the domestic value added induced by China's exports really belong to China?, China \& World Economy 20(5): 83-102. http://dx.doi.org/10.1111/j.1749124X.2012.01303.X

Eurostat 2016. Eurostat indicators on High-tech industry and Knowledge - intensive services. Annex 2 High-tech aggregation by NACE Rev 1.1 [online]. [cited 6 January 2016]. Available from Internet: http://ec.europa.eu/eurostat/cache/metadata/Annex es/htec_esms_an2.pdf

Gallego, N.; Llano, C. 2014. The border effect and the nonlinear relationship between trade and distance, Review of International Economics 22(5): 10161048. http://dx.doi.org/10.1111/roie.12152

Gomez-Herrera, E.; Martens, B.; Turlea, G. 2014. The drivers and impediments for cross-border ecommerce in the EU, Information Economics and Policy 28(1): 83-96.

http://dx.doi.org/10.1016/j.infoecopol.2014.05.002

González-Pernía, J. L.; Peña-Legazkue, I. 2015. Exportoriented entrepreneurship and regional economic growth, Small Business Economics 45(3): 505522. http://dx.doi.org/10.1007/s11187-015-9657-x

Håkanson, L. 2014. The role of psychic distance in international trade: a longitudinal analysis, International Marketing Review 31(3): 210-236. http://dx.doi.org/10.1108/IMR-04-2013-0079

Johnson, R. C.; Noguera, G. 2012. Accounting for intermediates: Production sharing and trade in value added, Journal of International Economics 86(2): 224-236. http://dx.doi.org/10.1016/j.jinteco.2011.10.003

Koopman, R.; Wang, Z.; Wei, S. J. 2014. Tracing valueadded and double counting in gross exports, American Economic Review 104(2): 459-494. http://dx.doi.org/10.1257/aer.104.2.459

Kostoska, O.; Mitrevski, P. 2015. Evaluating foreign trade specialization and qualitative competitiveness of a transition economy: the case of Macedonia, Empirica, 1-23.

http://dx.doi.org/10.1007/s10663-015-9308-0 
Lameli, A.; Nitsch, V.; Südekum, J.; Wolf, N. 2015. Same same but different: dialects and trade, German Economic Review 16(3): 290-306. http://dx.doi.org/10.1111/geer.12047

Lawless, M. 2010. Destinations of Irish exports: a gravity model approach, Journal of the Statistical and Social Inquiry Society of Ireland 39: 1-22 [online], [cited 4 January 2016]. Available from Internet:

http://www.scopus.com/inward/record.url?eid=2s2.0-80053015645\&partnerID=tZOtx3y1

Lowry, S. 2014. Small business administration trade and export promotion programs, in small business exports: analyses of promotion programs and impact of credit availability. Nova Science Publishers, Inc., 1-31 [online], [cited 4 January 2016]. Available from Internet:

http://www.scopus.com/inward/record.url?eid=2s2.0-84947560405\&partnerID=tZOtx3y1.

Mejía, J. F. 2011. Export diversification and economic growth. Heidelberg: Physica-Verlag HD. http://dx.doi.org/10.1007/978-3-7908-2742-2

Mirdala, R. 2015. Real exchange rates, current accounts and competitiveness issues in the Euro area,
Journal of Applied Economic Sciences 10(7): 1093-1124 [online], [cited 4 January 2016]. Available from Internet:

http://www.scopus.com/inward/record.url?eid=2s2.0-84956650306\&partnerID=tZOtx3y1.

OECD. 2015. Trade in Value Added (TiVA), in $O E C D$ WTO: Statistics on Trade in Value Added (database) - October 2015. http://dx.doi.org/10.1787/tiva-data-en

Sabonienè, A. 2014. Quality mode of Lithuanian manufacturing industry's exports, Engineering Economics 25(4): 450-457.

http://dx.doi.org/10.5755/j01.ee.25.4.6925

Verheyen, F. 2014. The role of non-price determinants for export demand, International Economics and Economic Policy 12(1): 107-125. http://dx.doi.org/10.1007/s10368-014-0281-z

Vukšić, G. 2015. Effects of private ownership, trade, and foreign direct investment on labor productivity growth in transition economies: evidence from the Croatian manufacturing industry, Emerging Markets Finance and Trade 52(2): 322-335. http://dx.doi.org/10.1080/1540496X.2015.1011540 